\title{
The Four-stage Values-based Chinese College Student Leadership Development Model
}

\author{
Wenyan Weng ${ }^{1, *}$, Wenfan Yan $^{2}$ \\ ${ }^{1}$ Institute of Leadership Studies, China Executive Leadership Academy Pudong, Shanghai, China \\ ${ }^{2}$ College of Education and Human Development, University of Massachusetts-Boston, Boston, USA
}

Email address:

wyweng a celap.org.cn (Wenyan Weng), wenfan.yan a umb.edu (Wenfan Yan)

${ }^{*}$ Corresponding author

\section{To cite this article:}

Wenyan Weng, Wenfan Yan. The Four-stage Values-based Chinese College Student Leadership Development Model. Humanities and Social Sciences. Vol. 7, No. 5, 2019, pp. 171-178. doi: 10.11648/j.hss.20190705.15

Received: September 15, 2019; Accepted: October 7, 2019; Published: October 24, 2019

\begin{abstract}
In the age of globalization and information, the core competitiveness among countries comes from the rising need of leadership talents, especially for young leaders. Within colleges in the United States, Leadership curriculum has been well developed, and leadership course standards as well as several theoretical models have been established. In contrast, there are no formal leadership development models in Chinese colleges. The value cultivation mechanism of Chinese college students has a lack of effectiveness. The values and principles of a leader are the key factors that determine their visions and goals. Values are the core of leadership. It is necessary to build formal leadership courses, especially the value-based leadership curriculum, in current Chinese universities and colleges. Based on Chinese values, philosophy, main national conditions and current leadership theories, a four-stage leadership development model was proposed and applied to several Chinese universities in Shanghai for several years. Specifically, this paper is based on a qualitative study that was conducted on six leadership courses in a Shanghai university of China. The two data sources included text analysis of 247 student learning summaries and focus group interviews of 34 selected outstanding student leaders. Based on the text analysis and focus group interviews, it is found that the value -based leadership development model has high student satisfaction and can help students to build positive values especially socialist core values in Chinese society. The model was approved to be more systematic and emphasizes students' subjectivity and internal psychological development trends which is from leadership psychology, leadership thinking, leadership concept to leadership behavior. It is argued that this model would help to explore value-based leadership with Chinese characteristics and can become a new way to apply value education in Chinese Colleges and Universities. Future research will focus on more empirical studies in other areas of China.
\end{abstract}

Keywords: Value-based, Student Leadership Development, Chinese Colleges

\section{Introduction}

In the age of globalization and information, the core competitiveness among countries comes from the rising need of leadership talents, especially for young leaders. The 19th National Congress of the Communist Party of China report clearly points out, "young leaders are an important force in realizing the Chinese dream. To win youth is to win the future and hope [1]. Under such circumstances, young leaders should take the socialist core values as guidance and establish leadership values of service for the youth with heart [2].
In China, the value cultivation mechanism of college students also show some characteristics, such as too much emphasis on collectivism and not enough attention on students' individual values or the students' subjectivity moral quality [3]. This kind of value cultivation mechanism, which emphasizes collectivism but ignores individualism, lacks respect for individual psychological needs and growth mechanism of students and easily leads to the disconnection between knowledge and action in value behavior [4]. The main socialist core values of education in Chinese universities is Ideological and Political Theory Courses, but many students do not like this kind of course [5]. Therefore, it is suggested to innovate the teaching methods of 
Ideological and Political Theory Courses and enhance the persuasiveness and appeal of Marxism [6]. Unifying social development with individual development is also necessary [7]. In the process of guiding and helping students to find personal values, social values should be immersed to build a stable and all-round value cultivation system.

In the USA, studies have shown that student leadership education in college can enhance national core values education in terms of civic responsibility and community participation of young students [8, 9]. The citizen participation and social responsibility are listed as the important learning goals of higher education by the American Association of Colleges \& Universities [10].

In China, the practice of student leadership education in several Shanghai universities has shown that student leadership education can improve students' values and develop their socialist corevalues. [11-13]. According to the surveys, college students who have studied leadership have shown more positive values than those who have not studied leadership [14-16]. In reviewing the pre-test and post-test of the student leadership projects, they have shown that student leadership education can promote their deep understanding and identification of values such as a sense of responsibility [17].

Based on Chinese value philosophy and current leadership theories, this paper proposed a four-stage value-based leadership development model. Based on this model, the value-based student leadership course was constructed for Chinese universities and colleges, then applied in several Shanghai universities and considered to be effective by some studies.

\section{Model Construction}

Can we build a value-based leadership development model from Chinese value philosophy and current leadership theories?

\subsection{The Four-stage Value Formation Process from Chinese Value Philosophy}

Li Deshun, the authoritative scholar of Chinese value philosophy addressed that human value is divided into two parts: self-value and social value [18]. How are human values formed? The forming process of values is essentially the process of self-seeking for dreams, visions and life goals, and the process of making clear who you are, what you need and who you want to be. He pointed out that the formation of values is a process of deepening, systematizing and making people's consciousness more explicit. In the process of understanding oneself, people can also recognize others and the external society. The process includes four stages: the value psychology, value recognition, value conceptualization and value behaviors. The value psychology includes the person's desire, the motivation, the interest, the emotion, the will and so on. Understanding the needs and interests of self, understanding their own advantages and interests, understanding their own empathy, self-control and other emotional traits such as a series of self-characteristics is the psychological precondition for values formation. Value recognition is the cognitive process of value formation. The value concept includes faith, belief and ideal. Faith is the main core value concept, which refers to the gradually formed concept that I believe in, such as the concept of selfimprovement, the concept of hard work, and the Marxist belief. The ideal is a vision of the future based on beliefs, such as personal ideals and life goals. Value behavior is the external expression of a person's values. As we mentioned," Thought determines behavior".

Once personal values are formed, they are not permanent. One will constantly evaluate their own existing values in the process of his life experience to strengthen or weaken some values. In many cases, people will modify and adjust the existing values after experiencing difficulties. Practical experiences are the highest standard of value evaluation. After the value concept is adjusted, it usually brings the corresponding value behavior change.

\subsection{Value-based Leadership Theories}

In recent years, various new leadership theories have followed the trend of emphasizing values. (1) Altrocentic leadership emphasizes others' values, focusing on helping others grow, serving others and improving social progress, world peace and environmental sustainability, etc. [19]; (2) Heart-Led Leader focuses on leaders' inner values and emphasizes that leaders should lead with their inner values and beliefs, such as respect, trust, empathy and collaboration [20]; (3) Healthy Leader focuses on "who you are" rather than "what you do". It is not about what you do, but what kind of person you are and what kind of personality and character you have [21]; (4) Centered Leadership begins with a clear perception of one's own inner values and strengths. A leader should find his own strengths, form his own style, and draw attention to his true inner needs and values. Only in this way can he become a mature, rational and an excellent leader [22]; (5) Maxwell believes that the navigation principle is based on the leader's values and the base of strategic foresight ability. It is one of the most important principles of leadership [23]; (6) Covey believes that finding your own values and inspiring others to find their own values is the eighth habit of excellent leaders and an important quality necessary for leaders in the era of Artificial Intelligence [24].

Among the latest value-based leadership theories, the most representative is Warren Bennis and Bill George. Becoming a leader is the process of becoming a complete person, as well as a process of self-exploration and self-growth [25]. He emphasizes that true leaders are self-reshaped and should form his own clear and firm values and a clear vision based on these values.

According to "Authentic Leadership", The values and principles of a leader are the key factors that determine a leader's vision and goals, as well as the compass in the leadership process. George indicates that knowing oneself is the way to find one's values [26].

They both addresses that hardship is one of the most 
fundamental elements of building a leader and building leaders' values. Only when the leader encounters hardships or difficulties can he clearly recognize his value orientation during value conflicts. Values are the life compass of their self-development.

Both Bennis and George believe that leaders explore their own values by self-reflecting and self-learning. However, they did not further discuss the psychological mechanism of forming leaders' inner values in the process of selfimprovement and form a model. What is the psychological mechanism in process of forming leaders' values?

\section{Method}

In this study, 256 outstanding student leaders who studied in East China University of Political Science and Law were enrolled in six sessions of leadership courses that lasted from the fall semester of 2012 to the spring semester of 2015. Each session lasted two and a half months.

The leadership course designed by the author highlights both value cognition and skills training, including knowledge teaching, leadership skills improvement and practical project.

\subsection{The Text Analysis}

All 256 students finished the leadership courses. They were required to submit a summary of their learning at the end of the course. The effective learning summary was 247 , and the effective rate was $96.5 \%$.

We analyzed key words and phrases in the 247 summaries, focused on how the leadership course influence students' values, and tried to explore and abstract the psychological mechanism of students' leadership values formation.

\subsection{Focus Group Interview}

In each session, we selected about 6 outstanding students in those who have completed the leadership course and conducted group interviews with them after the leadership course. The focus group interviews were conducted six times and lasted for around two hours each time. Every time five or six students were interviewed. 34 students were interviewed in total, all of whom were outstanding student leaders.

The interview questions are as follows: (1) What abilities and qualities should outstanding student leaders have? (2) What kind of abilities and qualities have you improved through the leadership course and why? Based on those questions, we analyzed the psychological mechanism of forming student leaders' values. All interviews were recorded and the texts were sorted out as the primary text materials for qualitative analysis. Some outstanding student leaders were also followed by further follow-up observation on their behavior changes, as an important basis for evaluating the effectiveness of leadership courses.

\section{Findings and Discussion}

\subsection{Building the Four-stage Value-based Student Leadership Development Model}

The curriculum is the basic approach for Chinese student leadership education. Leadership curriculum has been well developed in USA Colleges, and leadership course standards and several theoretical models have been established [27, 28]. In contrast, only a few of the more than 2000 universities and colleges in China have provided student leadership courses, which can be divided into three types: (1) Project-oriented leadership activities. This kind of leadership courses aim to develop students' leadership through various project activities designed and implemented by students. For example, activities to improve public policy, to organize festivals, to help vulnerable groups, and to protect cultural heritage, and so on. This kind of activities focus on improving students' leadership capabilities of self-management, project management, decision-making skills, communication skills, etc. During these activities, students also discuss the issues of leadership values such as responsibility and serving others [29]; (2) Skills-oriented leadership courses. By studying student leadership competency, the main content of leadership development is determined. For example, the leadership courses focus on improving students' leadership capability in decision-making, influence, communication, innovation and adaptability in Zhejiang University [30]; (3) leadership courses combining theories and skills. Based on recent leadership theories and student survey on the most relevant qualities and abilities of college student leaders in China, Southwest University of Finance and Economics provided the leadership curriculum which included two modules: leadership theory and leadership skills. In the skill module, self-recognition, influence-related skills and team building are designed based on the results of empirical research [31].

The values and principles of a leader are the key factors that determine a leader's vision and goals. Values are the core of leadership. These few Chinese student leadership courses focus on leadership ability and leadership practice, few pay attention to leadership values and how to integrate leadership ability and leadership practice in the process of cultivating leadership values.

In all, there are no formal leadership development model in Chinese Colleges. It is necessary to build the value-based leadership development model and apply it in the formal leadership curriculum and especially the value-based leadership curriculum in current Chinese universities and colleges.

The following model is based on theories of Chinese value formation and practice of student leadership education and commitment to improve the effectiveness of students' values cultivation. 


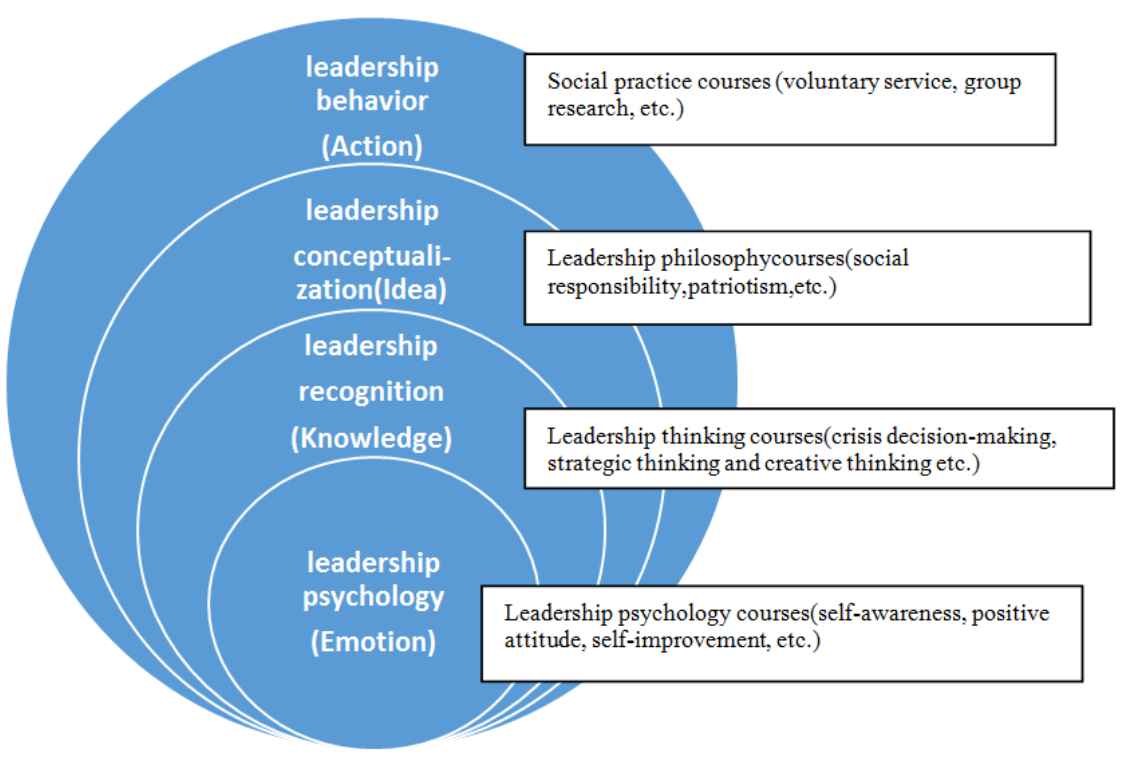

Figure 1. The four-stage value-based leadership development model.

\subsubsection{Leadership Psychology Courses Promote Experience of Value Psychology}

Leadership psychology courses aim to help students to build up intra-personal skills and discover who they are and what they want to be. In the leadership courses of this study, leadership psychology courses are designed to emphasize self-awareness and self leadership, so as to guide students to clarify their values during their self-exploration. This is not only the most critical stage in value formation, but also the most critical factor in value formation.

According to the text analysis of 247 summaries, the research team found that the course encouraged their selfreflection and self awareness and helped them to know more about their advantages and disadvantages (see Table 2).

Besides, according to the experiences of several other universities in Shanghai, leadership psychology courses are also arranged to emphasize self-awareness in their student leadership courses. For example, Shanghai University of Traditional Chinese Medicine offers a series of courses on "leadership and self-awareness". Shanghai Ocean University offers a series of student leadership courses including "selfimprovement leadership ", which includes:(1) positive psychology and happiness; (2) psychological stress relief and emotional management; (3) self-leadership; (4) improve selfimage and self-confidence; (5) reading club on leadership, etc. The University of Shanghai for Science and Technology set a 16-hour "Positive attitude" curriculum including a varies of development activities such as games, simulations and group discussions, etc. The curriculum aims to clarify the personal values and build up a positive and optimistic attitude when they face difficulties and challenges.

\subsubsection{Leadership Thinking Courses Promote Explicit Value Recognition}

In Chinese student leadership courses, there are many courses about leadership thinking such as strategic thinking and creative thinking, which can be reflected in the decisionmaking, communication, coordination and teamwork during the leadership process. We designed a crisis decision-making case in a communication course in this study. The course creates certain moral dilemma situation under the emergency, and require a student to make a decision under the value conflicts. Through these courses, we help students realize their inner values, and let them shape or reshape their values through self-evaluation and self-correction.

\subsubsection{Leadership Philosophy Courses Promote the Formation of Values}

We designed the Leadership philosophy curriculum focusing on Chinese socialist core values formulation. In China, socialist core values are summarized as follows: prosperity, democracy, civilization, harmony, freedom, equality, justice, the rule of law, patriotism, dedication, integrity and friendship. These values are the genes of China's philosophy and culture and they embody the ideals and beliefs that the Chinese people have worked so hard to establish [32].

We invited a team of high-end experts and professors according to relevant topics from top universities and academies or top leaders from diversity institutes.

This curriculum includes the site-visiting of various related places outside the school (called "on-site teaching") as well as in-class courses. For example, (a) patriotism education sites such as former residence and personal libraries of national heroes; (b) places showing great achievements of the reform and opening up in China such as Zhangjiang Science and Technology City, Yangshan Deep-water Port, etc. (c) some excellent government departments and enterprises such as TangQiao community of Pudong New Area, etc. These site-seeing courses can help students understand the history and reality around them and help to build their sense of social responsibility and patriotism. 


\subsubsection{Leadership Practice Courses Promote the Formation of Value-based Behavior}

The essence of value is practice [33]. People should prove the truth of their own thinking in practice. Only by exploring the problems in practice, can we truly understand the essence of value. Moreover, leadership is based on practice. Leadership practical projects are an important link to develop leadership and promote the formation of values. The projects include community volunteer services and group cooperative researches.

Community volunteer services aim to help students to conscientiously create a sense of service and enjoy the happiness of dedication. Students are required to choose some kind of volunteer activities in the school or out of school (in the community). Each student is required to complete at least 16 hours of volunteer service during the student leadership program.

Group cooperative researches require students to apply leadership skills and conduct empirical research on certain topics about community management or campus culture through group cooperation. It aims to promote more students to participate in social and campus activities, to enhance students' positive influence on others, the campus and the neighborhood community, to provide practical platforms for students' value formation.

These courses are student-centered and practical, in which teachers play the role of facilitator. Teachers are arranged to be the mentors of every group according to the certain research topic. Students can discuss with the mentors through interviews, emails or WeChat whenever they have problems. Teachers' support and mentoring system are important in the practical projects of this course.

\subsection{Findings of the Model's Effectiveness}

\subsubsection{Do Students Like the Value-based Leadership Course}

According to text analysis of 247 students' summaries, $83.0 \%(n=205)$ of students showed satisfaction with the value-based leadership courses. In other universities such as Shanghai University of Traditional Chinese medicine (2012-2017), Shanghai University of Science and Technology (2014-2017), and Shanghai Ocean University (2013-2016), students' satisfaction to their value-based leadership courses were all above $80 \%$ (most of them were above $90 \%$ ).

In contrast, value education in Chinese colleges and universities are mainly taught by direct introduction, which is the mainstream approach of student value education. But many students thought the course lacked of effectiveness [34, 35]. It's argued that the value-based leadership development model could be a value-building model that students like and are willing to accept. The value-based leadership course can be used as a new way of value education for Chinese college students.

\subsubsection{Does the Value-based Leadership Course Help to Build Students' Values}

The effectiveness of the value-based leadership development model: Does the leadership learning help students shape or re-shape their values?

(i) leadership courses help to improve students' positive values and self leadership

Based on the text analysis of 247 students' summary, it is found that the leadership education had influences on value formation of students and self-awareness in leadership development. (Tables $1 \& 2$ ).

Table 1. Influences on students' values formation through learning leadership.

\begin{tabular}{|c|c|c|}
\hline Contents & Rank & $\%(n) \quad N=247$ \\
\hline Improved the sense and skills of teamwork & 1 & $73.3 \%(181)$ \\
\hline $\begin{array}{l}\text { Inpired the awareness and behavior of } \\
\text { serving others actively }\end{array}$ & 2 & $68.0 \%(168)$ \\
\hline Stimulated the sense of responsibility & 3 & $49.4 \%(122)$ \\
\hline $\begin{array}{l}\text { Established a sincere and friendly attitude } \\
\text { and gained friendship }\end{array}$ & 4 & $48.6 \%(120)$ \\
\hline $\begin{array}{l}\text { Inspired personal dream, party beliefs, } \\
\text { patriotism and sense of mission }\end{array}$ & 5 & $30.0 \%(74)$ \\
\hline $\begin{array}{l}\text { Inspired the dedication to the team and the } \\
\text { collective }\end{array}$ & 6 & $20.6 \%(51)$ \\
\hline Established honest interpersonal attitude & 7 & $15.4 \%(38)$ \\
\hline $\begin{array}{l}\text { Recognized equality in interpersonal } \\
\text { relationships }\end{array}$ & 8 & $11.7 \%(29)$ \\
\hline
\end{tabular}

Table 2. Influences on students' self-leadership.

\begin{tabular}{lll}
\hline Contents & Rank & \%(n) N=247 \\
\hline $\begin{array}{l}\text { Had a new understanding of nature of leadership } \\
\text { and how to be a good student leader }\end{array}$ & 1 & $91.9 \%(227)$ \\
$\begin{array}{l}\text { Applied leadership in everyday life consciously } \\
\text { Developed self - reflection and had more clear }\end{array}$ & 2 & $83.8 \%(207)$ \\
understanding of self strength and weakness & 3 & $81.0 \%(200)$ \\
Motivated to develop self-leadership & 4 & $73.3 \%(181)$ \\
Broadened the vision and thinking & 5 & $17.0 \%(42)$ \\
\hline
\end{tabular}

Most students said that leadership education inspired their willingness to actively develop their self-leadership. Selfleadership development is the most important way to build one's leadership values.

As a student, Jiang said, "I think these courses are a good start for my leadership development. By having an understanding of leadership early inlife, we can better communicate with others, better serve others in student union and community, and better improve ourselves."

The leadership courses helped them to have a clearer selfawareness. Another student Sun said,

"Since my childhood I have undertaken a lot of class management positions, but every time I was being pushed to the position and have to do the jobs. Although I finished my jobs successfully and feel a sense of achievement. Now, these leadership courses help me gain self-awareness and selfconfidence. Next time, I will take the initiative to be a student leader and to serve others better."

(ii) leadership courses help to improve students' values especially Socialist Core Values at the individual level

Chinese Socialist Core Values have three levels including the national level, social level and individual level. At the national level, they are prosperity, democracy, civilization, harmony; Atthe social level, they are freedom, equality, 
justice, the rule of law; Atan individual level, they are patriotism, dedication, integrity and kindness.

According to group interviews of 34 outstanding student leaders and text analysis of 247 student summaries, it was found that the leadership course enhance them to build Socialist Core Values at the individual level including patriotism, dedication, integrity and kindness.

(a) Dedication: Student leaders showed more dedication to do their leadership work after learning from the leadership course.

Some students showed more positive dedication in daily work. As some students said, "when I form a team with my classmates to do something, I will take the initiative to stand up, put forward some suggestions or organize some activities to unite us." Another student said, "I am more enthusiastic to participate in team activities and to take on some team tasks, instead of pushing others to do things as usual."

This kind of dedication is embodied in respect for other students, listening to others' opinions more actively, having stronger comprehensive coordination ability and serving others more consciously, etc.

After the leadership course, Student Zuo was promoted from deputy minister of student affairs to minister. In the process of selecting his 11 deputy ministers and completing his leadership team, he applied what he learned in the leadership course and showed strong leadership. According to the principles that team members' abilities need to be complementary, he selected 11 deputy ministers with different specialties and combined them to form the strongest team in his own opinion. He also talks to unsuccessful candidates, explaining that it's not because they're incompetent, but because they don't fit the roles the team needs. His own role as a minister is to be in charge. This also reflects his dedication to work, considerately care for other students, and his values of dedication and kindness.

Some outstanding student leaders like Student Zuo, showed stronger enthusiasm for learning leadership after the leadership courses. They took the initiative to analyze and think about their work and experiences from the perspective of leadership and took the initiative to improve their leadership, which has reflected their positive leadership values based on Chinese Socialist Core Values.

(b) Kindness: Kindness is the ability to understand and care for others in the process of communicating with others. As Student Yan wrote in her summary, "in daily social life, I should pay more attention on understanding others, caring for others, and taking the initiative to communicate with others. I should not look down on those students who are born in poor families or have a poor appearance. I should conquer my fear and go outside of school to communicate and cooperate with more diversity people and improve my communicating skills. As teacher Weng said, put yourself in the other person's shoes is the golden rule in communication".

(c) Integrity: Serving others and doing things fairly with integrity and no selfish. So the leader can be prestige and will have an influence on others. Those are the core of team cohesion. As a student said,

"A good leader is not one who is arrogance, but one who shows modesty and has a sense of service and responsibility to others".

(d) Patriotism: Patriotism is related to social responsibility. A good leader should have the courage to take responsibility. That is to take responsibility for the consequences of personal decisions. As student Zhou said,

"A leader is not one who has a higher position, but one who is willing to undertake responsibilities which others are not willing to," 'A leader should recognize the impact of his personal decisions on his team, organization and even community, and should take responsibility for such consequences."

Patriotism is also one of Chinese socialist core values. After visiting Qian Xuesen Memorial Hall, a student wrote down his feeling in his summary:

"What shocked me most was the number of his books and collection, as well as his strong professional achievement and admirable personality. When thinking about my daily life, I often complain about the lack of interesting books. Even the textbooks of my professional courses cannot be read intensively. I realize that I'm lack of concentration and commitment in learning. This needs to be improved. Mr. Qian has contributed his whole life to the motherland. I'm deeply moved by his virtues. Someday, I want to make a contribution to the motherland like him."

In this case, Mr. Qian became the student's model of value formulation.

Another student felt the same way: when I entered Qian Xuesen Memorial Hall, I was deeply shocked. Mr. Qian has been concerned about national affairs all his life. He has been dedicated and giving to his country throughout his life. His great spirit is like the great light shining in my heart."

\section{Conclusion}

Based on Chinese value philosophy research and recent leadership theories, we proposed the four-stage leadership development model, and applied the model into Chinese student leadership education. As results showed, these kinds of leadership education can have positive influences on students' values formation.

This study assumed to build a value-based leadership curriculum system and education mechanism based on this mondel The curriculum system and education mechanism were approved to be: (1) It's more systematic and includes a four-stage curriculum system and dual mechanism (Internal and external). (2) It emphasizes students' subjectivity and their internal psychological mechanism, showing respect for student internal psychological development trends which is from leadership psychology, leadership thinking, leadership concept to leadership behavior. (3) It focuses on model demonstration and mentoring of others (including teachers and peers, etc.) in interpersonal influences. (4) It addresses 
the influence of social and community practice on forming students' values. Also, It is suggested that it is necessary to establish a comprehensive education mechanism combined universities, communities, enterprises and institutes, in order to support students' participation in practice. Students are encouraged to reflect on learning from practice and form the value concept of the unity of knowing and doing.

It is argued that this education mechanism would help to explore the value formation mechanism with Chinese characteristics, and also improve the future leader development. Future research will focus on more empirical study in other areas of China and exploring influence factors of value formation.

\section{Acknowledgements}

In this paper, the research was sponsored by China Scholarship Council, National Social Science Foundation (Project No. 12CKS044) and China Executive Leadership Academy Pudong (Project No. CELAP 2017-YJ-06).

\section{References}

[1] Xi J. P. Winning the Great Victory of Socialism with Chinese Characteristics in the New Era by Building a Well-off Society in an All-round Way: Report at the 19th National Congress of the Communist Party of China [R]. People's Publishing House, 2017.

[2] Xi J. P., The Governance [M]. China International Publishing Group, 2014: 172.

[3] Wei X. C., The Quality of Cultivating Moral Subjectivity: Important Proposition of Modern moral Education theory [J]. Education Research, 1996 (3).

[4] Qiu G. Y., Studies of Socialist Core Values Education [M]. People's Publishing House, 2014: 118-110.

[5] Xu G. Q., Empirical Analysis on the Integration of Socialist Core Values into National Education [J], Research on MAO Zedong and Deng Xiaoping Theory, 2014 (2): 44-49.

[6] Lan S. O., Investigation on the Status and Cultivation Methods of Socialist Core Values of "post-90s" Vocational College Students [J], Adult Education, 2013 (9): 45-47.

[7] Zhang S. Y., Dai Y. Q., An analysis on Core Values Education Paradigm: based on the Core Values Education in Singapore colleges and universities [J], MAO Zedong and Deng Xiaoping Theory Research, 2013 (9): 34-39.

[8] Zimmerman-Oster, K., Burkhardt, J. C. Leadership in the making: Impact and insights from leadership development designed in U.S. Colleges and universities [R]. The Battle Greek, MI: W. K. Kellogg Foundation. 1999. http://www.wkkf.org/.2007-06-08.

[9] Wagner, W. What is social change? In Komives, S. R. \& Wagner, W. (Eds.) Leadership for a better world: Understanding the social change model of Leadership development [M]. San Francisco, CA: Jossey - Bass. 2009: 741 .

[10] American Association of Colleges \& Universities [AAC\&U],
College learning for the New global century [M]. Washington, DC: Author. 2007.

[11] Weng, W. Y., Developing College Student Leadership: A New Carrier of Core Values Education in Chinese Colleges and Universities [J], Contemporary Educational Science, 2013 (11): 32-35.

[12] Xi, J. R., Strategic Thinking of Chinese Leadership Education for College Students [J], Contemporary Youth Research, 2012 (5): 23-28.

[13] Zhang Z. Q. \& Chen Z. Q., Analysis and Reflection on the value orientation of Student leadership education [J], Chinese Journal of Ideological and Theoretical Education, 2015 (2): 96.

[14] Weng, W. Y. \& Yan, W. F., Leadership for Social Change: findings from Chinese College Students [J]. Journal of Leadership, Accountability and Ethics, 2018, 15 (4): 120-129.

[15] Diao, J., Chen Z. Q. \& Zheng, F., A Study on the Social Responsibility Leadership of Shanghai University Students [J]. Contemporary Youth Research, 2013 (3): 77-84.

[16] Tao, S. L., Chinese college students leadership development and education model research [M]. East China Normal University Press, 2015, 76-88.

[17] Weng, W. Y., An empirical study on Student leadership Programs based on Chinese Socialist core values [J]. Journal of Youth Research, 2017 (3): 80-86.

[18] Li D. S. Axiology [M]. Beijing: China Renmin University Press, 2007.

[19] Vielmetter, G. \& Sell, Y. Leadership 2030: the six magetrends you need to understand to lead your company into the future [M]. New York: Hay Group Holding, Inc. 2014.

[20] Spaulding, T., The Heart Led Leader: how living and leading from the heart will change your organization and your life [M]. New York: Crown Business, 2015.

[21] Rosen, B., Grounded: How leaders stay rooted in an uncertain world [M]. Jossey-Bass. 2014.

[22] Barsh, J, \& Lavoie, J. Centered Leadership: Leading with purpose, clarity, and impact [M]. New York: Crown Business, 2014.

[23] Maxwell, J. C. The 21 Irrefutable Laws of Leadership: Follow Them and People will Follow You (10th Anniversary Edition) [M]. Harper Collins Leadership, 2012.

[24] Covey, S. R., The 8th Habits: From Effectiveness to Greatness [M]. Simon \& Schuster US, 2005.

[25] Bennis, W., On Becoming A Leader (4th Edition) [M]. Basic Book, 2009.

[26] George, B., Authentic Leadership: Rediscovering the Secrets to Creating Lasting Value [M]. Jossey-Bass, 2004.

[27] Mitstifer, D. I., Council for the Advancement of Standards Professional Standards for Higher Education. Council for the Advancement of Standards in Higher Education, Washington, D. C, 2012.

[28] Komives, S. R., Dugan, J. P., Owen, J. E., Slack, C., Wagner, W., et al., The Handbook for Student Leadership Development ( $2^{\text {nd }}$ ed.), San Francisco: Jossey-Bass. 2011. 
[29] Chen Y. K. Leadership Development [M]. The Commercial Press, 2011.

[30] Hu L. X., Developing and Training College Students' Leadership [M]. Zhejing University Press, 2011.

[31] Bian H. M. Student Leadership Development [M]. Southwest University of Finance and Economics Press, 2012.

[32] Xi J. P., The Governance [M]. China International Publishing Group, 2014: 170-171.
[33] Wang, Y. L., An analysis of the Nature of Value [J]. Journal of Academic Research, 2008 (8): 43-51.

[34] Tian, X. \& Wang, Y. F Survey of Socialist Core Values System Education for College Students, Journal of Ideological and Theoretical Education, 2010 (2): 82-86.

[35] Cheng E. F., Zheng Y. M., Feng Y. L., et al., Investigation and Research Report on the Construction of Socialist Core Value System in recent years, MAO Zedong and Deng Xiaoping Theories, 2011 (2): 23-30. 